San Jose State University

SJSU ScholarWorks

Master's Theses

Master's Theses and Graduate Research

Summer 2011

\title{
Patterns of Genetic and Morphological Variation in Deer Mice (Peromyscus Maniculatus) in the Warner Mountains
}

Allison Linnea Wade

San Jose State University

Follow this and additional works at: https://scholarworks.sjsu.edu/etd_theses

\section{Recommended Citation}

Wade, Allison Linnea, "Patterns of Genetic and Morphological Variation in Deer Mice (Peromyscus Maniculatus) in the Warner Mountains" (2011). Master's Theses. 4079.

DOI: https://doi.org/10.31979/etd.jupd-3xkp

https://scholarworks.sjsu.edu/etd_theses/4079

This Thesis is brought to you for free and open access by the Master's Theses and Graduate Research at SJSU ScholarWorks. It has been accepted for inclusion in Master's Theses by an authorized administrator of SJSU ScholarWorks. For more information, please contact scholarworks@sjsu.edu. 


\title{
PATTERNS OF GENETIC AND MORPHOLOGICAL VARIATION IN DEER MICE (PEROMYSCUS MANICULATUS) IN THE WARNER MOUNTAINS
}

\author{
A Thesis \\ Presented to \\ The Faculty of the Department of Biological Sciences \\ San Jose State University \\ In Partial Fulfillment \\ of the Requirements for the Degree \\ Master of Science
}

by

Allison L. Wade

August 2011 
(C) 2011

Allison L. Wade

ALL RIGHTS RESERVED 
The Designated Thesis Committee Approves the Thesis Titled

PATTERNS OF GENETIC AND MORPHOLOGICAL VARIATION IN DEER MICE (PEROMYSCUS MANICULATUS) IN THE WARNER MOUNTAINS

by

Allison L. Wade

APPROVED FOR THE DEPARTMENT OF BIOLOGICAL SCIENCES

SAN JOSE STATE UNIVERSITY

August 2011

Dr. John Matson Department of Biological Sciences

Dr. Leslee Parr Department of Biological Sciences

Stephanie Trewhitt Department of Biological Sciences 


\title{
ABSTRACT \\ PATTERNS OF GENETIC AND MORPHOLOGICAL VARIATION IN DEER MICE (PEROMYSCUS MANICULATUS) IN THE WARNER MOUNTAINS
}

\author{
by Allison Wade
}

A previously recognized north-south mitochondrial DNA (mtDNA) break in populations of deer mice, Peromyscus maniculatus, was investigated in Western North America. A 383-bp fragment of the mtDNA control region was analyzed from 107 tissue samples in the unstudied Warner Mountains of northeastern California. To determine if this north-south mtDNA break was also reflected in morphology, six cranial and mandibular measurements were taken from 72 deer mice. Using multivariate analysis of variance (MANOVA), it was determined that cranial characters did not vary significantly between the two mtDNA haplogroups, and discriminant function analysis (DFA) was unable to discriminate between the two haplogroups. Neutrality statistics and mismatch distribution analyses were performed on both mitochondrial haplotypes to test for recent demographic expansion. The analyses suggest that during Pleistocene glaciations, $P$. maniculatus persisted south of the glacial leading edge and in Pacific Northwest refugia. Upon retreat of the glaciers, refugial mice expanded from their glacial refuges, while populations south of the glaciers remained fairly stable. 


\section{ACKNOWLEDGEMENTS}

I would like to thank my thesis committee members for reviewing my work and for giving me guidance throughout this entire process. Jack, my advisor, introduced me to this research, joined me in the field for mice collection, and has taught me a lot along the way. He stuck with me over the many years it has taken to complete my master's. Leslee, my adopted advisor, took me into her lab as one of her own, gave me a place to work, and gave me the support I needed to get the molecular part of this project done. Stephanie was good company in the field, helped with collecting and preparing mice, and was always there if I needed help with something. I would also like to thank Joshua Mackie for the guidance he gave me on the molecular analyses.

I would also like to thank my fellow lab-mates Kenji, Amy, Jessie, Michael, Michele, Stephanie, Edith, and Veronica. They provided me with friendship, entertainment, motivation, and help. They contributed to my success and helped make my experience at San Jose State an enjoyable one.

Lastly, I would like to thank my family and friends who put up with me throughout this demanding process. I would like to thank my husband Chris for supporting me financially and emotionally through the multiple attempts at finishing my master's after we began a family. I would also like to thank my sister Laura, my mom Gail, and mother-in-law Elaine for the free babysitting that helped make this all possible. 


\section{Table of Contents}

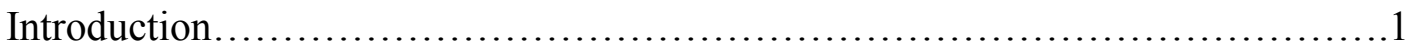

Methods and Materials.......................................................4

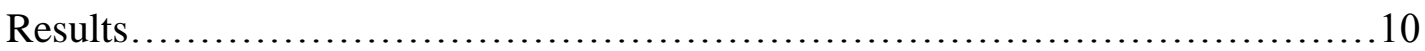

Discussion.............................................................. 16

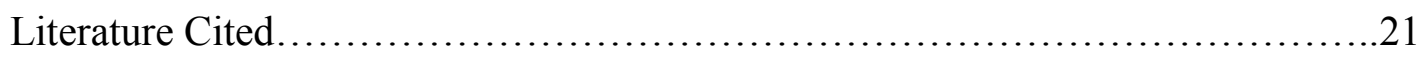




\section{List of Tables}

Table 1

Summary statistics for the 6 characters examined in

P. maniculatus at each locality....

Table 2

Pairwise $\mathrm{F}_{\mathrm{st}}$ estimates between localities. Bold values

designate significant differences between populations............................12

Table 3

Tests of neutrality statistics..............................................13 


\section{List of Figures}

Figure 1

Map showing the 3 sampling localities.......................................5

Figure 2

Neighbor joining (NJ) tree of mtDNA control region

data for 107 P. maniculatus sampled in this study.

Figure 3

Mismatch distribution plot for the Pacific Northwest clade.........................13

Figure 4

Mismatch distribution plot for the California clade

Figure 5

Results of discriminant function analysis performed on 6 cranial variables measured on 55 specimens representing the California and Pacific Northwest haplogroups............................... 15 


\section{INTRODUCTION}

Recently, many phylogeographic studies have been performed on both plants and animals in the Pacific Northwest (reviewed in Brunsfeld et al. 2001; reviewed in Shafer et al. 2010; reviewed in Soltis et al. 1997). Geologic events, such as recurring glaciations during the Pleistocene or the formation of the Sierra Nevada Mountain range, has led to several similar mtDNA phylogeographic patterns across numerous species in the Pacific Northwest (Brunsfeld et al. 2001; Shafer et al. 2010; Soltis et al. 1997).

Brunsfeld et al. (2001) identified three major distributional patterns for both plants and animals in the Pacific Northwest and also reviewed the genetic diversity of species with each distributional pattern. The "mesic forest disjunct pattern" refers to the disjunct distribution of conspecific populations between interior Rocky Mountain and Pacific coastal habitats, and these species often formed Pacific coastal and Rocky Mountain clades. The "Cascade/Sierran pattern" refers to the fact that many coastal species have their southern or northern limits at the transition between the Cascade and Sierra Nevada Mountains, while other species span this transition. Many of the "Cascade/Sierran" species consistently have a north-south genetic divergence. The "Northern Rocky Mountain pattern" refers to the non-uniform distribution of middle elevation species and the more widespread distribution of lower elevation species in the Northern Rocky Mountains.

Peromyscus maniculatus (North American deer mouse) is one of the most widespread species in North America (Hall 1981) and has been the subject of countless systematic studies (Avise et al. 1979; Chirhart et al. 2005; Koh and Peterson 1983; 
Lansman et al. 1983; Pergams and Ashley 1999; Yang and Kenagy 2009; Zheng et al. 2003).

Lansman et al. (1983) looked at the genetic diversity of $P$. maniculatus throughout its North American range and found five major genetic assemblages that correspond to geographic locality. The five genetic assemblages, distributed throughout western Canada and central and northwestern United States, include the "Texas-Mexico assemblage," "Northern Michigan assemblage," "Eastern States assemblage," "Southern California assemblage," and the "Central States assemblage."

Mitochondrial DNA divergences in P. maniculatus have been recognized (Avise et al. 1979; Dragoo et al. 2006; Lansman et al. 1983; Yang and Kenagy 2009). Particularly important in western North America is the study by Yang and Kenagy (2009), in which an mtDNA divergence separating $P$. maniculatus into Pacific Northwest and California haplogroups was identified, which was also consistent with the research of Dragoo et al. (2006) and Lansman et al. (1983).

The combination of both molecular and morphological data has proved useful in elucidating relationships and evolutionary history within and between species (Maldonado et al. 2004; Ordonez-Garza et al. 2010; Rodriquez and Ammerman 2004; and others). Ordonez-Garza et al. (2010) found that both mtDNA data and morphological data support the same phylogenetic relationships between three species of Peromyscus. Maldonado et al. (2001) performed a genetic analysis of Sorex ornatus (southern, central, and northern groups) and Sorex vagrans and found that the northern group of S. ornatus could not be differentiated from S. vagrans. However, S. ornatus and 
S. vagrans were found to be morphologically distinct groups (Maldonado et al 2004). Taken alone, the genetic and morphological data lead to different conclusions. Using both lines of evidence, Maldonado et al. (2004) hypothesized that since the three distinct groups of S. ornatus have likely been separated for more than 1 million years, S. vagrans was derived from an ancestor of the northern S. ornatus. Rodriquez and Ammerman (2004) found conflicting genetic and morpholgical data in the relationship between Myotis californicus and Myotis ciliolabrum. They concluded that these two species may be only one distinct species, or they diverged recently and experienced incomplete lineage sorting.

While Yang and Kenagy (2009) concentrated on the contact zone in Oregon, my research focused on a small area in northeastern California not studied by Yang and Kenagy (2009). The goals of this study were 3-fold: 1) to characterize mtDNA variation in populations of $P$. maniculatus from the Warner Mountains, California, 2) to determine if the populations of $P$. maniculatus in the Warner Mountains are included in the contact zone between the Pacific Northwest and California mice, as found by Yang and Kenagy (2009), and 3) to see if mtDNA variation is supported by variation in cranial morphology within populations. 


\section{MATERIALS AND METHODS}

Sample Collection-Deer mice (Peromyscus maniculatus) were sampled with Sherman live traps during the summer of 2005 from three different locations in California's Warner Mountains: 1) the head of the north fork of Parker Creek, Modoc County (PC), 2) Blue Lake Campground, Lassen County (BL), and 3) US Forest Service Road 42N09 at Shields Creek, Modoc County (SC) (Fig. 1). Deer mice were sacrificed by cervical dislocation. Specimens were either prepared on site or frozen and stored for preparation at a later date. Tissue from prepared specimens was stored in $95 \%$ ethanol and saved for subsequent examination. The procedures follow Protocol \#793 approved by the Institutional Animal Care and Use Committee at San Jose State University and follow the Animal Care and Use Committee Guidelines of the American Society of Mammalogists (Animal Care and Use Committee 1998). All specimens collected and prepared were deposited in the mammal collection at University of California Berkeley Museum of Vertebrate Zoology in Berkeley, California (MVZ Catalog \#'s 218851218991). 


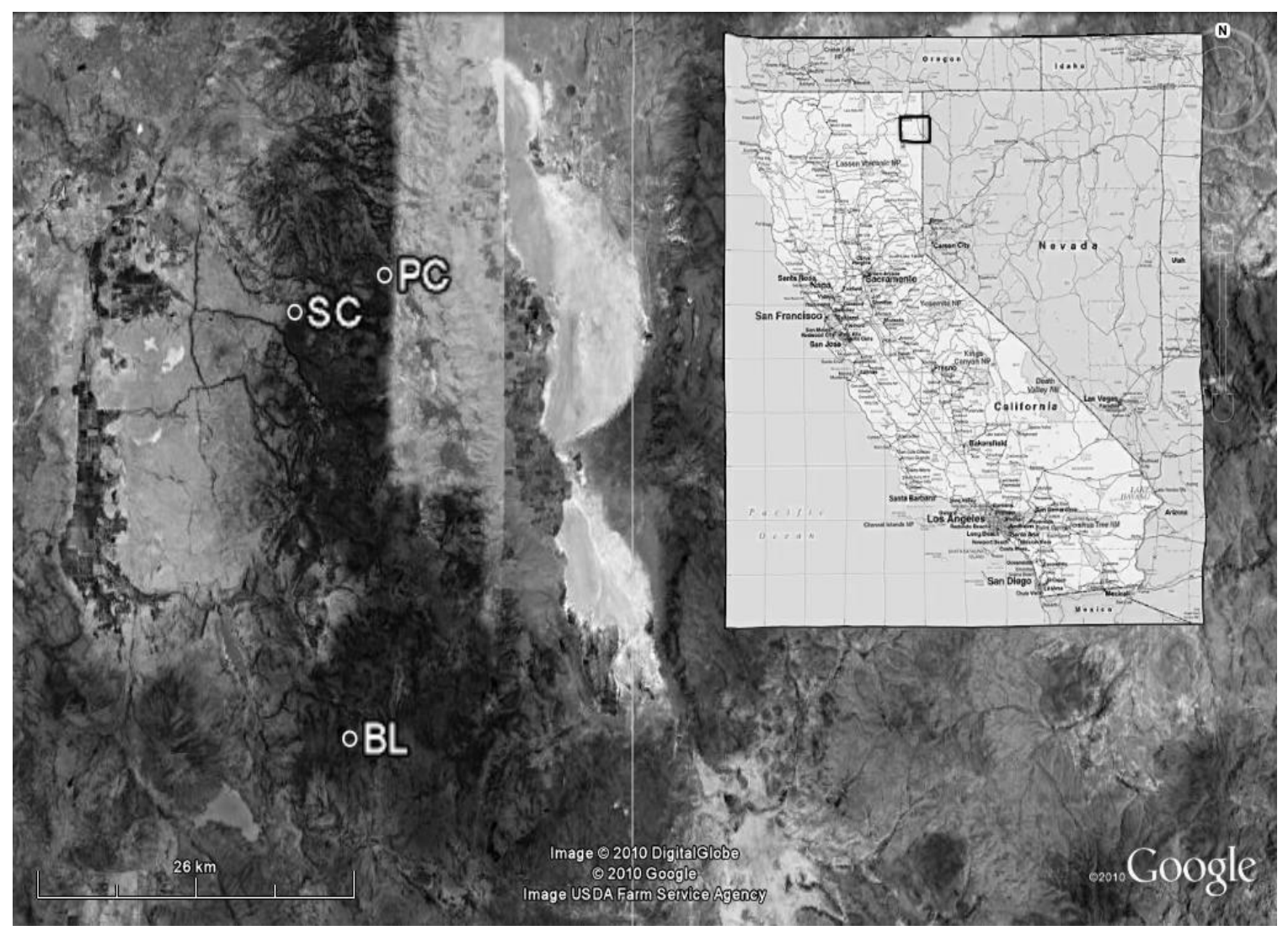

FIG. 1-Map showing the 3 sampling localities: head of the north fork of Parker Creek (PC), Blue Lake Campground (BL), and US Forest Service Road 42 N09 at Shields Creek (SC). Map adapted from Google Earth.

Molecular Analysis - Genomic DNA was extracted from alcohol-preserved muscle tissue using a Wizard Genomic DNA Purification Kit (Promega, Madison, Wisconsin), following the manufacturer's protocol. Rehydrated DNA was stored at $4^{\circ} \mathrm{C}$. Gel electrophoresis revealed the success of the DNA extractions in producing substantial amounts of DNA. 
For all mice samples $(\mathrm{n}=107)$ in which DNA was successfully extracted, a 383 base-pair region of the mitochondrial control region was amplified using the polymerase chain reaction $(\mathrm{PCR})$ and the primers $\mathrm{THR}$ 5'TCAAAGCTTACACCAGTCTTGTAAACC3' (Kocher et al. 1989) and TDKD 5'CCTGAAGTAGGAACCAGATC3' (Kocher et al. 1993). PCR was performed in a 25 $\mu \mathrm{l}$ reaction volume containing $0.5 \mu \mathrm{l}$ of a 1:100 dilution of DNA in TE buffer $(10 \mathrm{mM}$ Tris [pH 8.0] and $1 \mathrm{mM}$ EDTA), $50 \mathrm{mM} \mathrm{KCl,} 10 \mathrm{mM}$ Tris [pH 8.3], $0.2 \mathrm{mM}$ dNTPs (Fisher, Pittsburgh, Pennsylvania), $0.4 \mu \mathrm{M}$ forward primer THR, $0.4 \mu \mathrm{M}$ reverse primer TDKD, $0.4 \mathrm{mg} / \mathrm{ml}$ bovine serum albumin, $3.5 \mathrm{mM} \mathrm{MgCl}_{2}$, and 1 unit Taq DNA polymerase (AllStar, Sunnyvale, California). To ensure no contamination was present, a negative control using DNA-grade water instead of DNA was put in one of the reaction tubes. PCR was performed on a Personal Thermal Mastercycler (Eppendorf) with the following settings: initial denaturation at $95^{\circ} \mathrm{C}$ for 2 min., followed by 35 cycles of $95^{\circ} \mathrm{C}$ for $30 \mathrm{~s} ., 59.4^{\circ} \mathrm{C}$ for $1 \mathrm{~min}$., and $72^{\circ} \mathrm{C}$ for $1 \mathrm{~min}$., and then final extension at $72^{\circ} \mathrm{C}$ for 7 min.. Gel electrophoresis was performed to confirm lack of contamination and formation of desired product. PCR products were then sent to Geneway Research, Hayward, California for sequencing.

The 383 base-pair region of the DNA was aligned with BioEdit software version 7.0.5.3 (Hall 1999). A neighbor-joining tree was built with 10,000 bootstrap replicates and a Kimura 2-parameter model in Molecular Evolutionary Genetics Analysis (MEGA) version 4.1 (Tamura et al. 2007). Additional neighbor-joining trees using different 
models of nucleotide substitution, a maximum parsimony tree, and a minimum evolution tree were also created to lend further support for the original tree.

To look at population differentiation, $\mathrm{F}_{\mathrm{st}}$ pairwise differences were determined in Arlequin version 3.1 (Excoffier et al. 2005) using 10,000 permutations to test for significance at an alpha of $0.05 . \mathrm{F}_{\mathrm{st}}$ values between 0.0 and 0.05 indicate little genetic differentiation, values between 0.05 and 0.15 indicate moderate genetic differentiation, values between 0.15 and 0.25 indicate moderately great genetic differentiation, and values above 0.25 indicate very great genetic differentiation (Wright 1978). Negative $F_{\text {st }}$ values can result from the correction for unequal sample sizes utilized in the algorithm, so negative $\mathrm{F}_{\text {st }}$ values were considered to be a zero value.

The neutrality tests, Tajima's D, Fu's $F_{s}$, and Ramos-Onsins and Rozas' $R_{2}$ were performed to test for recent population expansion in the California and Pacific Northwest clades (Fu 1997; Ramos-Onsins and Rozas 2002; Tajima 1989). Both Tajima's D and Fu's $F_{s}$ were performed in Arlequin with 10,000 simulations and an alpha of 0.05 was used as the significance level for Tajima's D and an alpha of 0.02 was used as the significance level for Fu's $\mathrm{F}_{\mathrm{s}}$. Values for neutrality tests that are negative and significantly different than zero indicate an excess of rare polymorphisms and can be a sign of recent population expansion (Fu 1997; Tajima 1989). Ramos-Onsins and Rozas' $\mathrm{R}_{2}$ was performed in DnaSP using 10,000 replicates and an alpha of 0.05 was used as the significance level. The mismatch distribution using DnaSP was used as a comparable test for recent population expansion (Rogers and Harpending 1992). 
Morphological Analysis—-Specimens ( $\mathrm{n}=141)$ were put into one of two age categories (adult or sub-adult/juvenile) based primarily on the degree of closure of the basioccipital/basisphenoid cranial suture and secondarily on the degree of closure of the basisphenoid/presphenoid cranial suture and tooth wear (as defined in Koh and Peterson 1983).

The following six cranial and mandibular measurements (as defined in Koh and Peterson 1983) were taken from each adult North American deer mouse $(n=72)$ : greatest length of skull, greatest length of mandible, length of mandibular tooth row, width of brain case, length of hard palate, and width across upper first molars. Cranial and mandibular measurements were taken using a digital caliper (Fowler Ultracal III) and were recorded to the nearest $0.01 \mathrm{~mm}$. The selection of morphometric characters was based on the characters that other researchers commonly use and find informative (Landry and Lapointe 2001; Shipp-Pennock et al. 2005), and also on those characters that were found to have no significant differences across adult age classes of $P$. maniculatus since all adult mice were put into one age category (Koh and Peterson 1983). To maximize measurement consistency all cranial and mandibular measurements were taken by one person. In addition, $20 \%$ of the sample was measured a second time and these measurements were always within 5\% of the original measurements. Missing data due to damaged skulls were replaced with the mean from the population to which the specimen belonged $(n=5)$.

Previous research has shown that sex has no significant effect on morphological variation in P. maniculatus populations (Koh and Peterson 1983; Shipp-Pennock et al. 
2005). To ensure the sexes can be pooled into one group for statistical analyses, multivariate analysis of variance, MANOVA, (SPSS 2001) was performed on each population and all populations combined to determine the effect of sex on population variation.

Descriptive statistics (mean, standard deviation, standard error, and coefficient of variation) were calculated for each population (Table 1). MANOVA (SPSS) was used to ascertain whether morphometric characters significantly varied among populations and also among the two clades. Since discriminant function analysis, DFA, optimizes the separation of groups, it was used as a complimentary test to determine if the two genetic clades differ morphologically.

TABLE 1-Summary statistics for the six characters examined in $P$. maniculatus at each locality.

\begin{tabular}{|c|c|c|c|}
\hline \multirow[b]{2}{*}{ Character } & \multicolumn{3}{|c|}{ Measurements (mm) } \\
\hline & Parker Creek & $\begin{array}{c}\text { Blue Lake } \\
\text { Campground }\end{array}$ & $\begin{array}{c}\text { US Forest Service } \\
\text { Road 42N09 at } \\
\text { Shields Creek }\end{array}$ \\
\hline & $\overline{\mathrm{x}} \pm \mathrm{SE}$ & $\overline{\mathrm{x}} \pm \mathrm{SE}$ & $\overline{\mathrm{x}} \pm \mathrm{SE}$ \\
\hline Greatest length of skull & $25.01 \pm 0.151$ & $25.34 \pm 0.125$ & $25.05 \pm 0.152$ \\
\hline Greatest length of mandible & $15.42 \pm 0.095$ & $15.51 \pm 0.102$ & $15.49 \pm 0.107$ \\
\hline Length of mandibular tooth row & $3.37 \pm 0.031$ & $3.43 \pm 0.029$ & $3.46 \pm 0.029$ \\
\hline Width of braincase & $11.43 \pm 0.047$ & $11.48 \pm 0.047$ & $11.38 \pm 0.077$ \\
\hline Length of hard palate & $3.63 \pm 0.043$ & $3.68 \pm 0.042$ & $3.60 \pm 0.047$ \\
\hline Width across upper first molars & $4.69 \pm 0.024$ & $4.70 \pm 0.028$ & $4.74 \pm 0.045$ \\
\hline
\end{tabular}




\section{RESULTS}

Molecular Analysis - The mtDNA phylogenetic tree revealed two well supported distinct clades of mice with a bootstrap value of 93 (Fig. 2). Supplementary trees also supported the same two clades. Representatives of both clades were found in all three localities. When the Warner Mountain mtDNA specimens were compared with the sequences in Yang and Kenagy (2009), the sequences fell into the Pacific Northwest and California haplogroups that Yang and Kenagy (2009) had detected. 


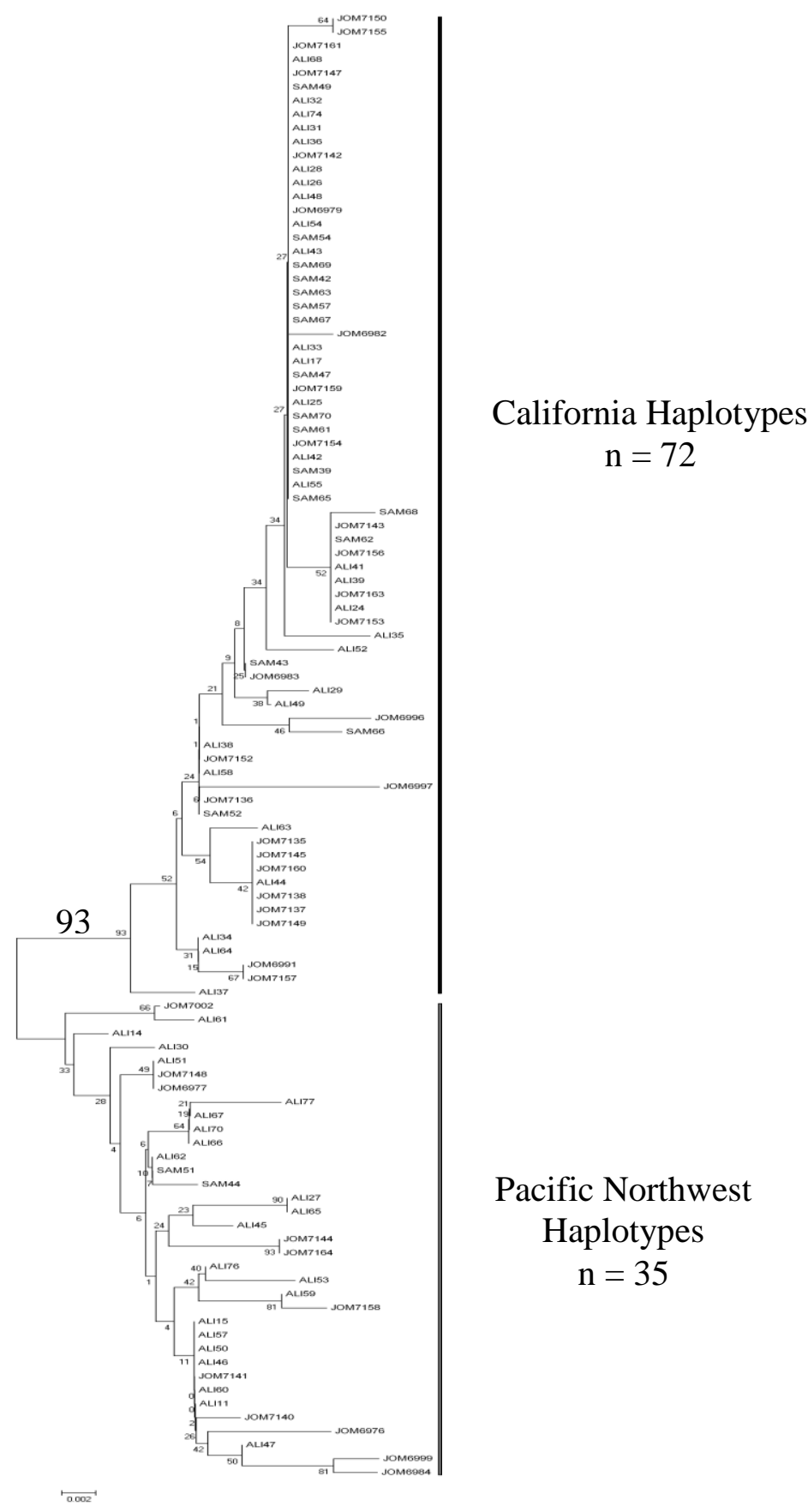

FIG. 2-Neighbor joining (NJ) tree of mtDNA control region data for 107 members of P. maniculatus sampled in this study. Support for the separation of California and Pacific Northwest haplotypes is given above the branch for NJ bootstrap replicates. 
There was moderate genetic differentiation between the populations at Parker Creek versus the US Forest Service Road 42 N09 at Shields Creek $\left(F_{\text {st }}=0.054\right)$ as well as between the populations at US Forest Service Road 42N09 at Shields Creek versus Blue Lake campground $\left(\mathrm{F}_{\mathrm{st}}=0.059\right)$ (Table 2$)$. There was very little genetic differentiation between the Parker Creek and Blue Lake Campground populations $\left(\mathrm{F}_{\mathrm{st}}=0.000\right)$. There was significant genetic differentiation between the Pacific Northwest and California clades $\left(\mathrm{F}_{\mathrm{st}}=0.747\right)$.

TABLE 2-Pairwise $\mathrm{F}_{\mathrm{st}}$ estimates between localities. Bold values designate significant differences between populations.

\begin{tabular}{lrr}
\hline & Parker Creek & Blue Lake Campground \\
\hline Blue Lake Campground & 0.000 & \\
Us Forest Service Road & $\mathbf{0 . 0 5 4}$ & $\mathbf{0 . 0 5 9}$ \\
42N09 at Shields Creek & & \\
\hline
\end{tabular}

The neutrality tests indicate that the Pacific Northwest haplogroup may have undergone a recent demographic expansion, while they do not support a recent demographic expansion for the California haplogroup (Table 3). The Pacific Northwest haplogroup had a statistically significant negative value of Fu's Fs $(-26.099, \mathrm{p}<0.001)$ and Ramos-Onsins and Rozas' $\mathrm{R}_{2}(0.065, \mathrm{p}<0.035)$ and did not have a statistically significant value of Tajima's D $(-1.434, \mathrm{p}=0.059)$. The California haplogroup did not have statistically significant values for Tajima's D $(-1.458, \mathrm{p}=0.052)$ or Ramos-Onsins and Rozas' $\mathrm{R}_{2}(0.054, \mathrm{p}=0.078)$ but had a statistically significant negative value of Fu's 
Fs $(-27.056, \mathrm{p}<0.001)$. The unimodal mismatch distribution of the Pacific Northwest haplogroup also supports the occurrence of recent demographic expansion (Fig. 3), while the multimodal mismatch distribution of the California haplogroup does not (Fig. 4).

TABLE 3 - Tests of neutrality statistics. Bold values designate significant values ( $p<0.05$ for Tajima's D and Ramos-Onsins and Rozas' $\mathrm{R}_{2}$ and $\mathrm{p}<0.02$ for Fu's $\mathrm{F}_{\mathrm{s}}$ ).

\begin{tabular}{lrrr}
\hline & Tajima's D & Fu's Fs & Ramos-Onsins and Rozas' R \\
\hline Pacific Northwest & -1.434 & $\mathbf{- 2 6 . 0 9 9}$ & $\mathbf{0 . 0 6 5}$ \\
California & -1.458 & $\mathbf{- 2 7 . 0 5 6}$ & 0.054 \\
& & & \\
\hline
\end{tabular}

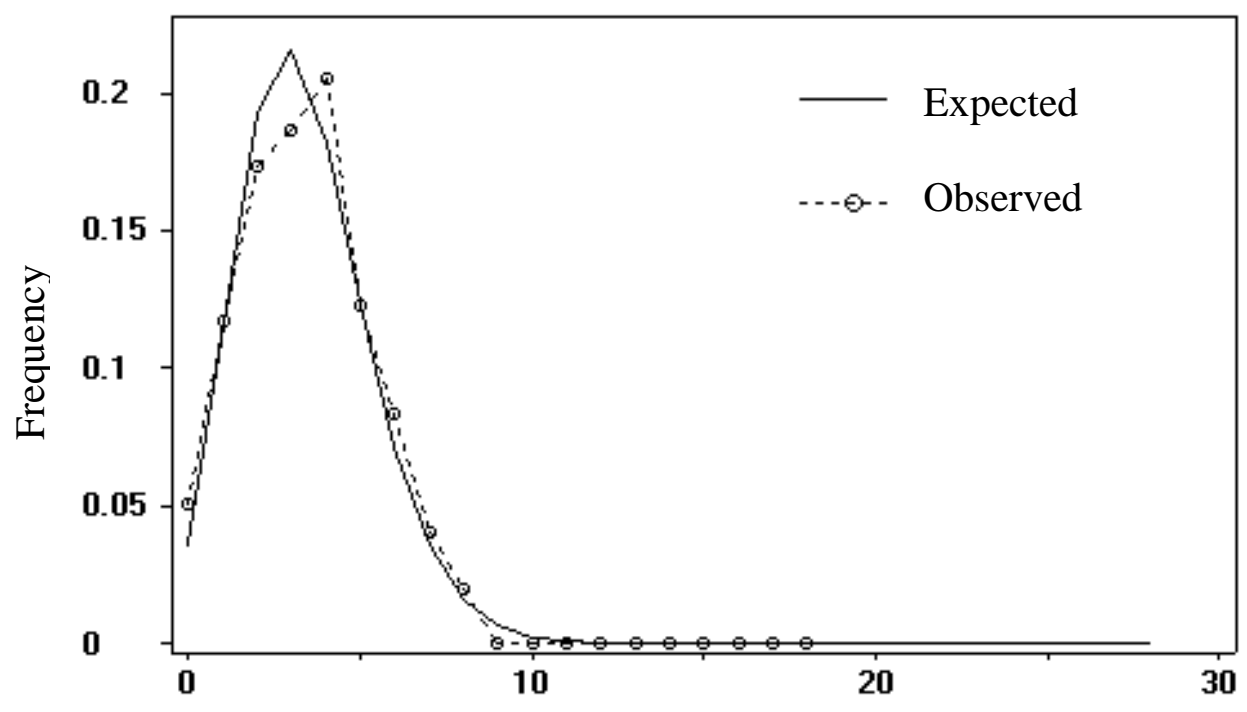

Number of Pairwise Differences

FIG. 3-Mismatch distribution plot for the Pacific Northwest clade. The unimodal mismatch distribution reflects demographic expansion of the Pacific Northwest haplogroup. 


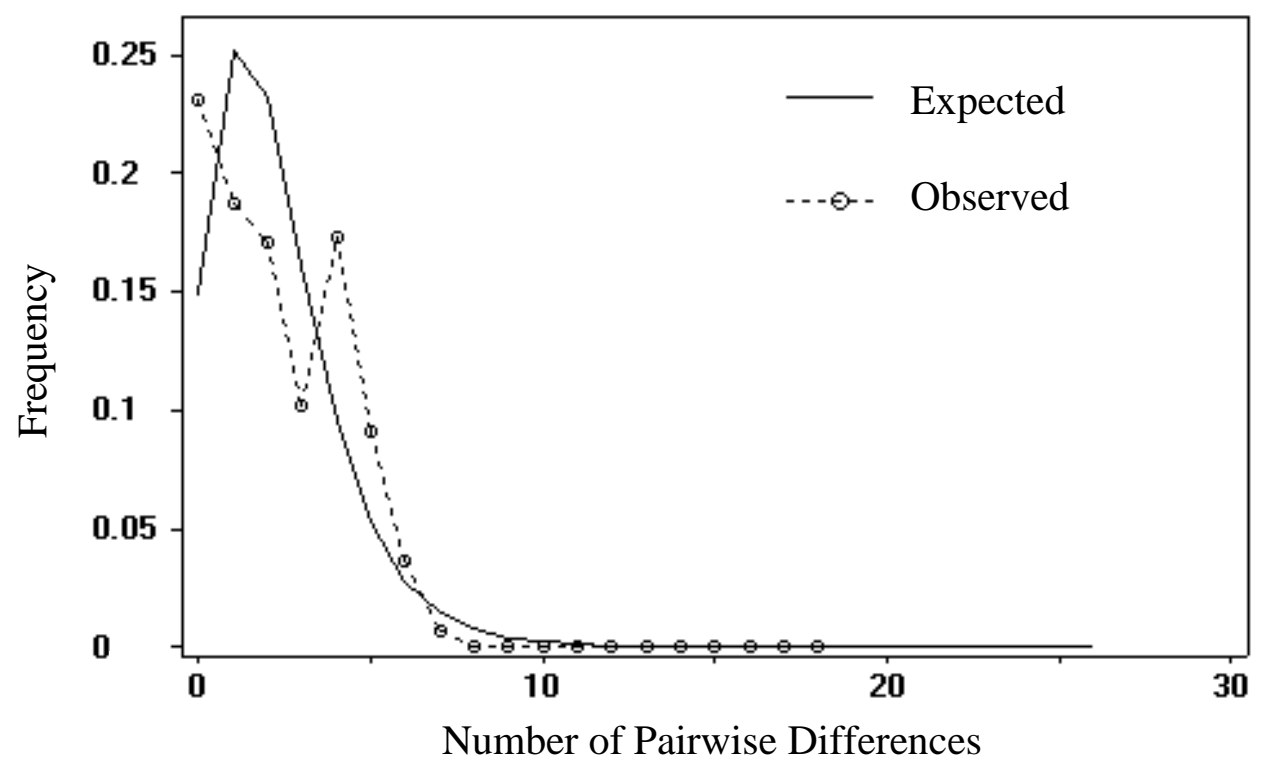

Fig. 4-Mismatch distribution plot for the California clade. The multimodal mismatch distribution does not support the occurrence of demographic expansion of the California haplogroup.

Morphological Analysis—Sexual dimorphism was not statistically significant within any of the $P$. maniculatus populations: PC (Wilks' $\lambda=0.832, \mathrm{~F}_{1,21}=0.538, \mathrm{p}=$ 0.772), BL (Wilks' $\lambda=0.644, \mathrm{~F}_{1,28}=2.118, \mathrm{p}=0.090$ ), $\mathrm{SC}$ (Wilks' $\lambda=0.510, \mathrm{~F}_{1,17}=$ $1.921, \mathrm{p}=0.158$ ). Sexual dimorphism was not evident when all three populations were combined (Wilks' $\lambda=0.863, \mathrm{~F}_{1,70}=1.717, \mathrm{p}=0.131$ ). Since there was no significant variation in morphometric characters between sexes, males and females were lumped into one group.

Using MANOVA the cranial characters did not vary significantly among populations (Wilks' $\lambda=0.850, \mathrm{~F}_{1,70}=0.903, \mathrm{p}=0.546$ ) or between the two clades 
(Wilks' $\lambda=0.812, \mathrm{~F}_{1,53}=1.851, \mathrm{p}=0.109$ ). Discriminant function analysis was unable to discriminate between the two clades (Wilks' $\lambda=0.812$, Chi-square $=10.406, \mathrm{p}=$ 0.109). When predicting group membership, discriminant function analysis misidentified group membership $34.5 \%$ of the time (Fig. 5).

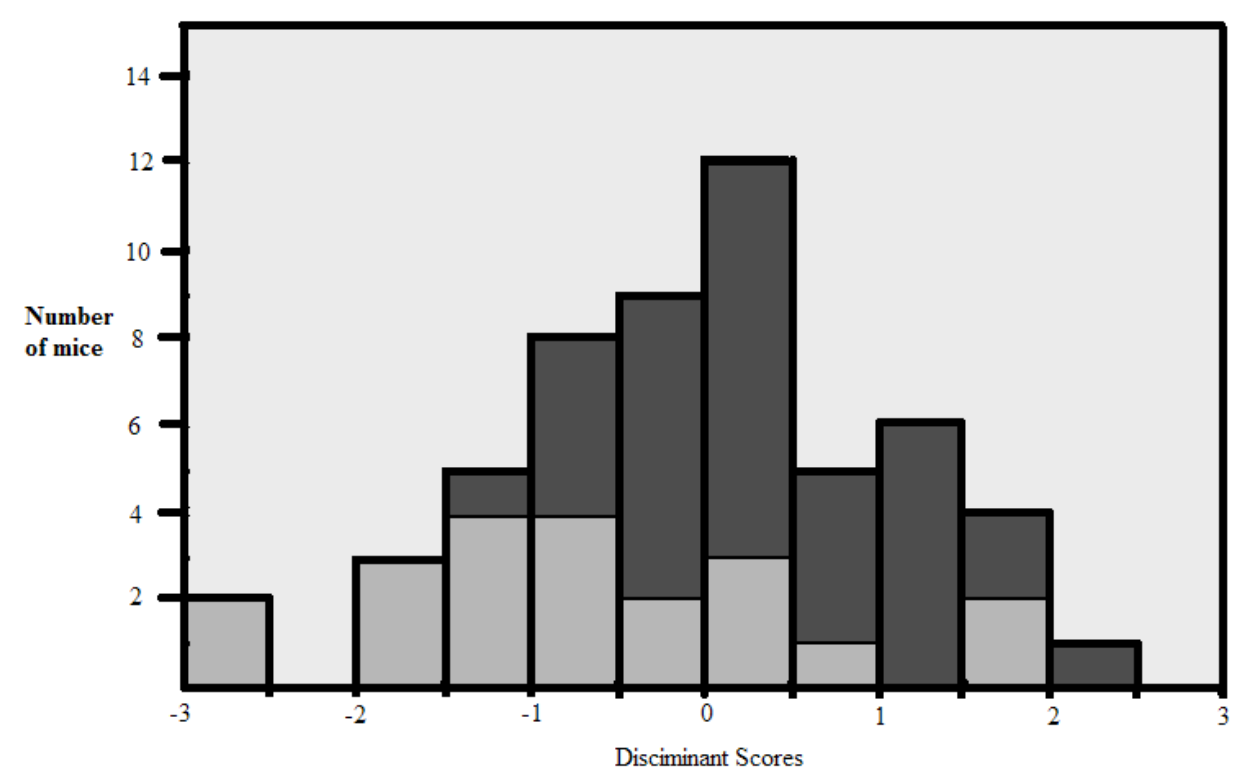

FiG. 5-Results of discriminant function analysis performed on six cranial variables measured on 55 specimens representing the California and Pacific Northwest haplogroups. California haplotypes are indicated in dark grey and Pacific Northwest haplotypes are indicated in light grey. 


\section{DISCUSSION}

The two strongly supported mtDNA haplogroups found in the Warner Mountains are consistent with the mtDNA breaks revealed by Dragoo et al. (2006), Lansman et al. (1983), and Yang and Kenagy (2009). Analysis of a subset of GenBank sequences included in the research of Yang and Kenagy (2009) suggest the two mitochondrial clades correspond to the Pacific Northwest and California haplotype groups in their study. There is an overlap zone of the Pacific Northwest and California clades in southern and eastern Oregon and in northern coastal and eastern California (Yang and Kenagy 2009).

There was little to no genetic differentiation between the three populations of $P$. maniculatus in the Warner Mountains, which would suggest that there is gene flow between these populations. However, there was great genetic differentiation between the California and Pacific Northwest haplogroups, further supporting the conclusion of this phylogenetic analysis and the research of Yang and Kenagy (2009) that there are two distinct mitochondrial haplogroups. It is important to note that a mitochondrial DNA break does not necessarily indicate a break in gene flow. Yang and Kenagy (2009) showed that, while there is a mitochondrial genetic break in the Pacific Northwest and California mice, there is no such break in the nuclear DNA, indicating that the two haplogroups are not reproductively isolated.

There are a number of species of vertebrates (e.g., Ascaphus truei/montanus complex, Rana pretiosa complex, Wilsonia pusilla, Microtus richardsoni, Tamias amoenus, and others) in western North America that have a coastal-central DNA 
divergence, in which one haplogroup occupies habitat along the Pacific coast and the other more inland, often with a gap of unoccupied land in between (Brunsfeld et al. 2001; Shafer et al. 2010). The formation of the Sierra Nevada Mountain Range and the resultant rain shadow effect are thought to have played a role in causing this genetic break. Lansman et al. (1983) found an mtDNA divide that separated the "Central States Assemblage" and "California Assemblage" of P. maniculatus. While Lansman et al. (1983) found a coastal-central mitochondrial divergence that can be attributed to a geographic barrier (Sierra Nevada Mountains), my research and that of Yang and Kenagy (2009) indicated a north-south mitochondrial divergence in P. maniculatus where no apparent geographic barrier exists. North-south mitochondrial divergences in numerous western North American species (Batrachoseps wrighti, Dicamptodon tenebrosus, Oreamnos americanus, Peromyscus maniculatus, Phenacomys longicaudus, Strix occidentalis, and others) have also been identified without the presence of geographic barriers (Brunsfeld et al. 2001; Shafer et al. 2010; Soltis et al. 1997; Yang and Kenagy 2009). Similar phylogeographic patterns among organisms, such as the north-south pattern observed in the Pacific Northwest, have been ascribed to a shared Pleistocene glacial history (Hewitt 1996). Yang and Kenagy (2009) concluded that the Pacific Northwest/California mitochondrial DNA pattern with the lack of a geographic barrier was the product of past biogeographic events, such as glaciations during the Pleistocene. Yang and Kenagy (2009) suggest that because contemporary North American deer mice have widespread distribution in boreal forest habitat and are generalists that the same is true for deer mice in the past. As glaciers advanced and habitat became 
unsuitable, North American deer mice persisted south of the glacial leading edge and in coastal refugia and nunataks in the Pacific Northwest (Pielou 1991).

The neutrality tests and mismatch distribution indicate that the Pacific Northwest haplogroup underwent a recent demographic expansion, while the California haplogroup has been relatively stable demographically. This is consistent with the findings of Yang and Kenagy (2009). The environment of the California haplogroup was not broken up by glaciations during the Pleistocene and more recent past. Therefore, it makes some sense that the haplogroup would not have undergone recent population expansion. Their current distribution means that California populations of $P$. maniculatus have retreated from their late Pleistocene range and have been displaced by the southward movement of the Pacific Northwest haplogroup (Zheng et al. 2003). This premise is supported by the statistical analyses that suggest the California haplogroup has not undergone a recent demographic expansion. Upon retreat of the glaciers, the Pacific Northwest haplogroup, which persisted in glacial refugia, expanded to its current distribution in western North America. Refugia are thought to have been dispersed sporadically along coastal northwestern North America and on offshore islands, such as the Queen Charlotte Islands and Vancouver Island (Fladmark 1979; Pielou 1991).

Like P. maniculatus, Oreamnos americanus (mountain goat) is thought to have persisted south of the glacial leading edge and in Pacific Northwest refugia during the Pleistocene glaciations. Unlike in this study, Shafer et al. (2011) discovered a northsouth mitochondrial divide in $O$. americanus and found evidence of recent demographic 
expansion in both the northern and southern haplogroups. It is not surprising that different species might respond differently to the retreat of the Pleistocene glaciers.

Although this study did not include nuclear DNA, it is likely that the California and Pacific Northwest haplogroups interbreed as suggested by Yang and Kenagy (2009). It is primarily the nuclear DNA that carries the genes that dictate the cranial morphology of $P$. maniculatus. So it also is not surprising that the morphological comparison between the California and Pacific Northwest mice could not discriminate between the two haplogroups.

Molecular tools have confirmed (Avise et al. 1979; Miyamota 1987; Shoshani et al. 1996; Zheng et al. 2003), refuted (Bond et al. 2001; Echelle and Mosier 1981; Lansman et al. 1983), and resolved (Bowen et al. 1991; Hillis et al. 1983) previous understandings of evolutionary relationships. Before molecular techniques were in common use, the basis of our understanding of the relationships between organisms was their morphology. While some phylogenies created with morphology have been dismissed in lieu of molecular data (Gatesy et al. 1999; and others), many of them remain and have been confirmed through use of molecular data (Avise et al. 1979; Miyamota 1987; Shaw 2002; Shoshani 1996).

P. maniculatus has been the subject of numerous phylogeographic studies (Dragoo et al. 2006; Lansman et al. 1983; Yang and Kenagy 2009; Zheng et al. 2003). Future phylogeographic studies on other murid rodents that occupy the Pacific Northwest, such as Neotoma cinerea or Ondatra zibethicus, would be interesting to compare to this study. Sampling over the entire western range and the use of both 
mitochondrial and nuclear DNA are crucial for a better understanding of the species evolutionary history. 


\section{LITERATURE CITED}

Animal CARE AND Use CommitTeE. 1998. Guidelines for the capture, handling, and care of mammals as approved by the American Society of Mammalogists. Journal of Mammalogy 79:1416-1431.

Avise, J. C., R. A. LAnsman, AND R.O. Shade. 1979. The use of restriction endonucleases to measure mitochondrial DNA sequence relatedness in natural populations. I. Population structure and evolution in the genus Peromyscus. Genetics 92:279-295.

Bond, J. E., M. C. Hedin, M. G. RamiReZ, And B. D. Opell. 2001. Deep molecular divergence in the absence of morphological and ecological change in the Californian coastal dune endemic trapdoor spider Aptostichus simus. Molecular Ecology 10:899910.

Bowen, B. W., A. B. Meylan, And J. C. Avise. 1991. Evolutionary distinctiveness of the endangered Kemp's ridley sea turtle. Nature 352:709-711.

Brunsfeld, S. J., J. Sullivan, D. E. Soltis, And P. S. Soltis. 2001. Comparative phylogeography of northwestern North America: a synthesis. Pp. 319-339 in Integrating Ecological and Evolutionary Processes in a Spatial Context. Blackwell Science, Oxford.

Chirhart, S.E., R. L. Honeycutt, AND I. F. Greenbaum. 2005. Microsatellite variation and evolution in the Peromyscus maniculatus species group. Molecular Phylogenetics and Evolution 34:408-415.

Dragoo, J. W., J. A. Lackey, K. E. Moore, E. P. Lessa, J. A. Cook, And T. L. Yates. 2006. Phylogeography of the deer mouse (Peromyscus maniculatus) provides a predictive framework for research on hantaviruses. Journal of General Virology 87:1997-2003.

Echelle, A. A., AND D. T. MosIER. 1981. All-Female fish: A cryptic species of Menidia (Atherinidae). Science 212:1411-1413.

ExCOFFIER, L., G. LAVAL, AND S. SCHNEIDER. 2005. Arlequin ver. 3.0: An integrated software package for population genetics data analysis. Evolutionary Bioinformatics Online 1:47-50.

FLADMARK, K. R. 1979. Alternate migration corridors for early man in North America. American Antiquity 44:55-69. 
FU, Y-X. 1997. Statistical Tests of Neutrality of Mutations Against Population Growth, Hitchhiking and Background Selection. Genetics 147:915-925.

Gatesy, J., M. Milinkovitch, V. Waddel, And M. Stanhope. 1999. Stability of cladistic relationships between Cetacea and higher level artiodactyls taxa. Systematic Biology 48:6-20.

Hall, E. R. 1981. The Mammals of North America. John Wiley and Sons, New York.

HALL, T.A. 1999. BioEdit: a user-friendly biological sequence alignment editor and analysis program for Windows 95/98/NT. Nucleic Acid Symposium Series 41:95-98.

HewitT, G. M. 1996. Some genetic consequences of ice ages, and their role in divergence and speciation. Biological Journal of the Linnaean Society 58:247-276.

HiLlis, D. M., J. S. Frost, AND D. A. WRIGHT. 1983. Phylogeny and biogeography of the Rana Pipiens complex: A biochemical evaluation. Systematic Zoology 32:132143.

Kocher, T. D., J. A. Conroy, K. R. McKaye, And J. R. Stauffer. 1993. Similar morphologies of cichlid fish in Lakes Tanganyika and Malawi are due to convergence. Molecular Phylogenetics and Evolution 2:158-165.

Kocher, T. D., W. K. Thomas, A. Meyer, S. V. Edwards, S. PaAbo, F. X. VillablanCA, AND A. C. WILSON. 1989. Dynamics of mtDNA evolution in animals: amplification and sequencing with conserved primers. Proceedings of the National Academy of Sciences 86:6196-620.

KoH, H. S., AND R. L. Peterson. 1983. Systematic studies of deer mice, Peromyscus maniculatus Wagner (Cricetidae, Rodentia); analysis of age and secondary sexual variation in morphometric characters. Canadian Journal of Zoology 61:2618-2628.

LANDRY, P. A., AND F. J. LAPOINTE. 2001. Within-population craniometric variability of insular populations of deer mice, Peromyscus maniculatus, elucidated by landscape and configuration. Oikos 95:136-146.

Lansman, R. A., J. C. Avise, C. F. Aquadro, J. F. Shapira, and S. W. Daniel. 1983. Extensive genetic variation in mitochondrial DNA'S among geographic populations of the deer mouse, Peromyscus maniculatus. Evolution 37:1-16.

MALDOnAdo, J. E., F. HERTEL, AND C. VILA. 2004. Discordant patterns of morphological variation in genetically divergent populations of ornate shrews (Sorex ornatus). Journal of Mammalogy 85:886-896. 
Maldonado, J. E., C. Vila, AND R. K. WAYNE. 2001. Tripartite genetic subdivisions in the ornate shrew (Sorex ornatus). Molecular Ecology 10:127-147.

Miyamota, M. M. 1987. Congruence among character sets in phylogenetic studies of the frog genus Leptodactylus. Systematic Zoology 30:281-290.

Ordonez-Garza, N., J. O. Matson, R. E. Strauss, R. D. Bradley, and J. SAlazarBRAVO. 2010. Patterns of phenotypic and genetic variation in three species of endemic Mesoamerican Peromyscus (Rodentia: Cricetidae). Journal of Mammalogy 91:848-859.

Pergams, O. R. W., AND M. V. Ashley. 1999. Rapid morphological change in Channel Island deer mice. Evolution 53:1573-1581

PIElou, E. C. 1991. After the Ice Age: the Return of Life to Glaciated North America. University of Chicago Press, Chicago, Illinois.

RAMOS-ONSINS, S. E., AND J. ROZAS. 2002. Statistical properties of new neutrality tests against population growth. Molecular Biology and Evolution 19:2092-2100.

RodrigueZ, R. M., AND L. K. AMmERmAN. 2004. Mitochondrial DNA divergence does not reflect morphological difference between Myotis californicus and Myotis ciliolabrum. Journal of Mammalogy 85:842-851.

Rogers, A. R., AND H. HARPENDING. 1992. Population Growth Makes Waves in the Distribution of Pairwise Genetic Differences. Molecular Biology and Evolution 9:552-569.

Shafer, A. B. A., S. D. Cote, And D. W. Coltman. 2011. Hot spots of genetic diversity descended from multiple Pleistocene refugia in an alpine ungulate. Evolution 65:125138.

Shafer, A. B. A., C. I. Cullingham, S. D. Cote, And D. W. Coltman. 2010. Of glaciers and refugia: a decade of study sheds new light on the phylogeography of northwestern North America. Molecular Ecology 19:4589-4621.

SHAW, K. L. 2002. Conflict between nuclear and mitochondrial DNA phylogenies of a recent species radiation: What mtDNA reveals and conceals about modes of speciation in Hawaiian crickets. Proceedings of the National Academy of Sciences 99:16122-16127.

Shipp-Pennock, M. A., W. M. D. Webster, And D. W. Freshwater. 2005. Systematics of the white-footed mouse (Peromyscus leucopus) in the mid-atlantic region. Journal of Mammalogy 86:803-813. 
Shoshani, J., J. P. Groves, E. L. Simons, And G. F. GunNells. 1996. Primate phylogeny: morphological vs molecular results. Molecular Phlyogenetics and Evolution 5:102-154.

Soltis, D. E., M. A. GitZendanner, D. D. STRenge, AND P. S. Soltis. 1997. Chloroplast DNA intraspecific phylogeography of plants from the Pacific Northwest of North America. Plant Systematics and Evolution 206:353-373.

SPSS FOR WINDOWS, REL. 11.0.1. 2001. Chicago: SPSS Incorporated.

TAJIMA, F. 1989. Statistical Method for Testing the Neutral Mutation Hypothesis by DNA Polymorphism. Genetics 123:585-595.

TAmura, K., J. Dudley, M. NeI AND S. Kumar. 2007. MEGA4: Molecular Evolutionary Genetics Analysis (MEGA) software version 4.0. Molecular Biology and Evolution 24:1596-1599.

WRIGHT, S. 1978. Evolution and the Genetics of Populations vol. 4, Variability Within and Among Natural Populations. University of Chicago Press, Chicago, Illinois.

YANG, D. S., AND G. J. KENAGY 2009. Nuclear and mitochondrial DNA reveal contrasting evolutionary processes in populations of deer mice (Peromyscus maniculatus). Molecular Ecology 18:5115-5125.

ZhenG, X. G., B. S. ARbogast, And G. J. KenaGy. 2003. Historical demography and genetic structure of sister species: deermice (Peromyscus) in the North American temperate rain forest. Molecular Ecology 12:711-724. 